\title{
Miranda
}

Revue pluridisciplinaire du monde anglophone /

Multidisciplinary peer-reviewed journal on the English-

speaking world

13 | 2016

Thomas Spence and his Legacy: Bicentennial

Perspectives

\section{AS - Reflectional Encounters : Dans le Miroir à Retournement Temporel.}

Michael Joyce

\section{OpenEdition}

Journals

Electronic version

URL: http://journals.openedition.org/miranda/9405

DOI: $10.4000 /$ miranda.9405

ISSN: 2108-6559

\section{Publisher}

Université Toulouse - Jean Jaurès

Electronic reference

Michael Joyce, "AS - Reflectional Encounters : Dans le Miroir à Retournement Temporel.", Miranda [Online], 13 | 2016, Online since 22 November 2016, connection on 16 February 2021. URL: http:// journals.openedition.org/miranda/9405; DOI: https://doi.org/10.4000/miranda.9405

This text was automatically generated on 16 February 2021

\section{(c) (1) () $\Theta$}

Miranda is licensed under a Creative Commons Attribution-NonCommercial-NoDerivatives 4.0 International License. 


\title{
AS - Reflectional Encounters : Dans le Miroir à Retournement Temporel.
}

\author{
Michael Joyce
}

When I was invited to give a talk at the 2014 journées d'études internationales considering "Corps techniques et environnements connectés" ${ }^{1}$ which took place at the University of Paris 8 in June 2014, I had my misgivings about what I might offer that inquiry, although the organizers did much to assuage my anxiety in pointing me to those aspects of my "novel of internet" Was : annales nomadique that, "while not focused on 'technical bodies and networked environments' per se" surely addresses such questions. Then, as often happens when one is invited to think explicitly about one's own themes, I began to think-perhaps delude myself is the better term-that in my fictions as well as my more recent collaborative media work I have for some time been involved, plus ou moins, with exactly these questions.

2 Already of course, apropos of the technical body, I have here indulged in a sleight of hand in my-so to speak-off-hand remark about having been "for some time," depuis quelque temps, involved with these questions. It is of course exactly the nature of our experience of that "some," ce quelque, that networked environments bring into question, doing so in what we imagine to be some different way than we have experienced time before, and thus in a way that makes us question the vehicle within, or through which, we experience ourselves as experiencing. Indeed in the face of the technical body-forgive me, such wordplay is inevitable and invariably adolescent I think, since we are only in the adolescence of l'homme technologiquement modifié and thus, like all ados, supremely self-conscious about the face we show the world- our self-consciousness is multiplied by the technical body's fundamental circuitry of selfawareness, one that sometimes makes the Biblical expression "the left hand doesn't know what the right hand is doing" painfully literal.

In turning to considerations of such "some times" in my own work and how they may help us to consider the embodiment of le sujet digital, I want to begin not with Was but with what I jokingly call my great lost work, Twilight, a symphony, a hyperfiction issued on $\mathrm{CD}$ just at the moment that the web was in its first blossom and the CD-ROM was 
waning. Thereafter I will turn briefly to Was and its vision of what might perhaps be seen in Foucauldian terms as a heterotempora, or heterotopic networked time, before talking for a time about a current collaborative work in process, The Surface of Water, an augmented-reality blended panoramic narrative that I'm doing with Jay Bolter and Maria Engberg. Finally, by way of envoi, I will offer a provocation, borrowed from the physicist and artist Dominique Peysson of EnsadLab, whose musings on the work of her fellow physicist Mathias Fink at ESPCI Paris Tech, I hope will not only serve to unpack the title for this essay, but perhaps offer a way to consider the temporality of events in punctuated time that I would suggest to some degree characterizes the experience of the technical body in networked space. That said, as will become painfully obvious, these are the reflections of a writer not a philosopher.

Thus I would like to acknowledge that, were I either courageous or capable enough, it might be more profitable, more apt, richer, and less nostalgic to have discussed these works in the context of two more contemporary philosophical texts. The first is what Claudia Hart calls "Mark Hansen's mod" of the Deleuzian Any-Space-Whatever, l'espace quelconque into its digital version, where for Hansen "affection comprises a bodily supplement, a response to a digital stimulus that remains fundamentally heterogeneous to human perceptual (visual) capacities." (208). The second is Karen Barad's "lively dance of mattering," in Meeting the Universe Halfway which draws upon Nils Bohr, Donna Haraway, Judith Butler, and Michel Foucault among others to propose "a posthumanist performative approach to understanding technoscientific and other naturalcultural practices" (135) where "mattering itself acquires meaning and form through the realization of different agential possibilities" and "[t]emporality and spatiality emerge in...processual historicity."(141) These will largely have to await another essay.

In the brief excerpt from Twilight that I follow, an episode that I sometimes refer to as bargain-basement Proust, the main character, Hugh, is riding his bicycle in the same place that he rode a day before and meditating upon that temporal retracing. I think one catches a glimpse of the emerging self-conscious technical body here in Hugh's musing :

Having been here once here now once again. One could actually reach and touch where in the air there before the eyes the center of the body had been bound by bone staves, a heavy kettle of innards slung below corseted bellows; reach where once a winged shoulder moved at eye level, so surely there one could lay one's head against the scent of the past itself, nestle in memory, cradle recurrence between curved palms: one really passed here once before, each interval of space sprocketed, gelled, sound-striped, imperceptibly variable yet not film but real life or, if not that, time itself imprinted in air and fragrant earth : that snakelike mark in the still damp mud where the tire pressed beneath one's weight marks the passage not of time but the meaning of a life, a phrase as weighty and as lost as the echo of one's passing, passage, past.

I tread here once and am once again. What could this mean?

When one thinks of the ways that the velo offers an early instance of the technical body's engagement in a network, one naturally turns to Walter Benjamin's remarks in The Arcades Project about the "Similarity of the arcades to the indoor arenas in which one learned to ride a bicycle...[and in which] halls the figure of the woman assumed its most seductive aspect: as cyclist." One result of this displacement according to Benjamin is that "The woman as cyclist competes with the cabaret singer for the place 
of honor on posters, and gives to fashion its most daring line." (62) That is, he connects the velodrome and the arcades as sites of not just the emergence of fashion but of a certain kind of ubiquitous posterization and exhibitionism which in its commodification is drained of eroticism, not unlike our contemporary experience of such images on the web, Facebook, Pinterest, Instagram, Vine and so on.

7 I have written elsewhere (2001) about how Benjamin points to "the advent of new velocities, which gave life an altered rhythm" in which regard he quotes Maurice Talmeyr's La cité du sang from 1900 : "These [poster] images of a day or an hour, bleached by the elements, charcoaled by urchins, scorched by the sun...symbolize to a higher degree even than the newspapers the sudden, shock-filled, multiform life that carries us away." (65) One might easily ask-although characteristically for The Arcades Project Benjamin does not directly-whether we see this multiform life as other or rather as an emergent, twinned, self.

8 In his notion of the arcades as medial spaces for the embodied city to see itself, Benjamin does however prefigure our own preoccupations not simply with seeing oneself, but seeing oneself seeing oneself (or seeing oneself being seen). This self seen and being-seen that likewise appears in Hugh's meditation in Twilight, of course comes to prominence in the reduplicative modes of fashion, pornography, and the selfie ; as well as, I will come to suggest, in our experience of locative fictions and augmented reality.

9 That my character, Hugh, intent on following the precise track that his bicycle has made the previous day, turns his thought to the cinema is, on the one hand, simply a matter of surface resemblance : the pattern of a mountain bicycle tire in the muddy path reminds him of a strip of film, causing him to see the whole of his retracing of his track as an "interval of space sprocketed, gelled, sound-striped." While I can't claim any of the qualities of those of Mark Hansen's "Bergsonist vocation," nor am I quite capable of keeping in mind, let alone parsing, Deleuze's dissection of Bergson's movement-image into perception-, action-, and affection-image, Hugh's meditation nonetheless perhaps offers an instance of affect's "coincidence of subject and object" wherein the subject, according to Deleuze, "experiences itself from the inside." (65). Hugh surely does take proprioceptive measure, as if from within, of the fully embodied, prior, temporally twinned him, whose "kettle of innards slung below corseted bellows" has passed here before and lingers in persistence of memory if not of vision.

10 All this, of course, recalls Benjamin's filmic sense of the arcades, wherein the fashionable shopper and the flâneur alike experience themselves from the inside through les meneaux of the vitrines that frame them. Indeed the art historian T. J. Clark in reviewing The Arcades Project speaks of how "Benjamin seems to have dreamed of a final, rapid-fire, cinematic delivery, accelerating to the speed of exchange-fact after fact, image after image, with relations between them somehow revealed by the glitter and breathlessness of the juxtapositions." (Clark 4)

11 What I want to do is to extend the question of what it means to be in the same place twice to what it means to be in the same place twice at the same time, that is to double or even multiply oneself in la forme de multinaéité that the statement of the journées d'études imagined and with which the smart body seductively beckons. Indeed the introductory screen of Twilight seems to describe such a "multinaeity" wherein "The stories... move in two central arcs, east toward life (though in the past) and west toward death (though in the future)." The still point where such arcs intervene (a word I 
choose over "connect" here in order to suspend the interval of experiencing oneself from the inside) offers a punctuated temporality, where the future and the past intermix and a newness bursts forth. Benjamin famously suggests something similar in the "Awakening" section of the $\mathrm{N}$ convolute of The Arcades Project in terms of the nature of image :

It's not that what is past casts its light on what is present, or what is present its light on the past; rather, image is that wherein what has been comes together in a flash with the now to form a constellation. In other words, image is dialectics at a standstill. For while the relation of the present to the past is a purely temporal, continuous one, the relation of what-has-been to the now is dialectical: is not progression but image, suddenly emergent. - Only dialectical images are genuine images ... and the place where one encounters them is language. (462)

I am not going to venture into the literature of speculation and explication that trails like glittering ice behind the comet of Benjamin's Whiteheadian dialectical image save to note in passing Max Pensky's suggestion that Benjamin's "elimination of theory in favor of method" was "utterly distinctive of [his] intellectual trajectory" and "in fact 'theory' in its oldest sense : theology" (181), which Pensky sees as marked by "the interruption of the truly heterogeneous into the continuum of repetition, that is, the dialectical image as an event of a new time." (193-94) I will return to Pensky later, in talking about panoramas and The Surface of Water, but for now I want to turn to the punctuated temporality-the events of a new time- of my novel Was.

In the statement I wrote for the jacket copy for Was, like Benjamin I located the emergent place of encounter in language and its moment at a still point where :

Its title figure, the word was, marks that instant of utterance outside the present, which is neither past nor future but rather the interstitial space of any telling... Story begets story as if without author, events gathering into each other, as much memory as dream, their locales literally moving across the face of the globe by instants... strob[ing] across its surface like thunderstorms seen from a satellite. Yet in these brief flashes a ... procession of characters passes before us in vignette.

If this evocation of strobing synaptic elements brings to mind Benjamin's vision of how "what has been comes together in a flash with the now to form a constellation," it may be because the notion of constellated knowledge has long attracted me. In an essay from the 90's I spoke of the computer as "a theatre of longings [wherein] desires that [have become] transparent in print culture suddenly reappear as clearly as the shadows they have always been." Responding to the prevalent claim that what was then called the MTV generation lacked an attention span, I argued for the presence of a new temporality "which privileges polyvocality, multiplicity, and constellated knowledge" and where "a sustained attention span may be less useful than successive attendings." $(2000,74)$

Hugh's meditation on time in Twilight avoids the verb was: "Having been here once here now once again," he says and then "I tread here once and am once again," until finally casting for the subjunctive "What could this mean," as if seeking in the theatre of longings the flash of the suddenly emergent. In Was, however, each time that longing reaches a still point, the stories move on, with the result that the self-aware, self-seeing subject is distributed in a smear of light as well as creolized language. The novel's method is the collapse of the border into image, which is to say (as the jacket copy notes) vignette. The word "vignette" comes from the old French diminutive for vigne, and alludes to the vine as a decorative framing figure. Etymologically, the meaning of vignette "transferred from the border to the picture itself, then ... to a type of small 
photographic portrait with blurred edges" (Online Etymological Dictionary) with the literary sense of vignette arriving quite late in the $19^{\text {th }}$ century. (unpaginated)

Toward the end of the novel (143-144) a collection of physical vignettes is collaged within a kind of Wunderkammer in a scene where a circumnavigating woman sailor, a female Odysseus, having lunch beside the sea in Greece, allows an old man to woo her away on the back of his moto to show her his house and beyond it a shack wherein he presents a

jeweled spectrum within fragrant dark wood, the carefully fitted boards of polished rosewood covered over ceiling to floor with layers of richly coloured and undulant surface of roadway vignettes, luggage stickers and city emblems, binièta from all over (Italia, Deutschland, Suiza, Monaco, California U. S., he recited a brief census), the swirling overlay of engraved patches decoupaged with a gold substance like honey, resin or wax, a glowing collage of baroque decoration, finally more Italian than Greek

ché stanza bella! she sighed, unable to keep from the wrong language

A ogni uccello il suo nido è bello, he replied proudly, an Italian proverb : every bird thinks its own nest is beautiful

kallisto she whispered praying that was the right word

drive camion, truck, 18 wheels (smiles proudly), all over for fifty year, even to Manchester London, Baghdad, Istanbul

shook her head vigorously understanding, yes, yes, parakalo' kalime'ra, she wanted to say thank you, great but suspected she had maybe said goodnight

my wife he die four year now, before bring binièta from every country for her smiling

efcharisto' efcharisto', he said, kissing the back of her hand where he had drawn the vignette upon it

she found herself wordlessly crying

maybe you marry ? he asked and she could not tell if it was meant as a proposal or a prophecy

17 The verging of the funereal into the conjugal here, the decoupaged golden casket into a marital bed, is of course intentional. Embodiment folds inward from its edges in the way that Mark C. Taylor situates hypertextuality within a context of reversibility and invagination wherein, "since the organism as a whole is formed by a complex of dermal layers, the body is, in effect, nothing but a strata of skin in which interiority and exteriority are thoroughly convoluted." (12) Similarly for Karen Barad "memory is the enfoldings of space-time matter written into the universe" (ix) with temporality "produced through the iterative enfolding of phenomena marking the sedimenting historiality of differential patterns of mattering" wherein time itself "has a history." (180)

18 In each of the scenes of this so-called novel of internet, the question at hand is what was there, a question that elides seamlessly into where do we find ourselves. "What was there" is, you may know, the name of a primitive augmented reality smartphone app, a kind of crowd-sourced digital decoupage that takes on the form of a locative 
historiography, a tourist guide, an epigraphy, overlaying prior forms of a current building, park, or square as images projected upon its location even if the former buildings are now ghosts and the parks paved over.

The app offers an exemplary instance of how locative dispositifs fix us, however briefly, in a version of Foucault's heterotopic "place without place" (2571) and how apparatuses, in Karen Barad's phrase, are "boundary-making practices" (148). One need not extend the plane of visualization or immersion from the prosthetic, protrusible eye of the uplifted iPhone to the goggle-eyed cyborg transparency of Google glasses to recognize that the experience these eyes offer functions almost four-dimensionally, adding temporality to the experience of proprioceptive presence and depth. Such apparatuses extend Foucault's observation that it is "from the mirror that I find myself absent from the place where I am as long as I see myself there" (2571) to encompass the experience of finding myself present in a place no longer there, not merely by seeing myself there, but-as I suggested earlier-seeing myself seeing myself (or seeing myself being seen) there. There, as in the shifting locales of Was, we might be said to inhabit those "places outside of all places, even though they are at the same time effectively localizable," places of the sort that led Foucault to suggest the possibility of constructing a heterotopology as "the challenge at once mythical and real of the space where we live." (2571)

It is to the permeation of the mythical and the real in the technical body within the heterotopological/heterotemporal scape that I wish to turn to in looking at the current collaborative digital work in progress that I am involved in, The Surface of Water and Fictional Encounters. The work regards the life of the Swedish painter Anders Zorn who lived from 1860-1920 and enjoyed significant success not just in Sweden but especially in the United States as well as in France where he trained. As a transitional figure between formal portraiture and impressionism, Zorn's paintings of kings, presidents, princes of industry and their ladies, depict the dissolution of the discrete body into distributed space. Perhaps his best-known painting, of Isabelle Stuart Gardner at her Venice palazzo during a festival, is literally a liminal portrait as she bursts into the drawing room through the doorway from her balconata overlooking the Grand Canal. In a monologue from our work she describes the portrait, its

flush of face and eyes reflecting the rosy blush of the spent fireworks beyond, pale hands thrust out gaily, and yet with a faintly scandalous hint of ecstasy in the way the spread fingers gripped the casement, the ivory of the gown glowing yellow like a calla lily unfurling, the figure of the lily repeated in the almond-shaped form in which he draped my pearls in a long oval from my neck to my center where the ruby glowed, its deep red exploding into the brighter streak of a red rocket against the sky beyond my shoulder.

On our project website Maria Engberg describes its method as

fusing, an interweaving of different verbal, visual, and sonic languages...[with] English, Swedish, and French...braided into a macaronic poetic language that allows individual voices from Zorn's life to speak...[midst] multimodal panoramas [of] 360 degree photography, representations of Zorn's paintings, historical photographs and site-specific sounds...[where] nature painting, impressionistically treated landscape panoramas, and black-and-white documentation photography [blend] the "here and now" with the "there and then."

The question at hand is where the space that the "here and now" blends with the "there and then" is located, or better still where and when it takes place, and how we experience it. In his essay "The Digital Panorama and Cinemascapes" Rod Coover notes 
how their "layered and composited elements ...often disrupt the authoritative stance of objectivity," disrupting "the verisimilitude that is established through fixed and naturalistic relations of ... documentary photographic panoramas...[as] elements from outside the temporal-spatial frame of the photographic moment are layered upon the image." (199). I would argue, however, that such disruption is increasingly fundamental to locative experience. To the question set forth at the beginning of the workshop statement-le temps du numérique est-il un présent continu sans mémoire?-I would offer as a provisional reply that le temps du numérique est un présent interrompu avec mémoire, et même par la mémoire, albeit perhaps memory of a particularly suspended type. Like the dialectical image and the heterotopological scape, locative media suspend the moment of experiencing oneself within a bracketed present. This experience I think shares an affinity with neuroscientist and novelist David Eagleman's notions of how subjective duration is linked to the complexity of our experiences, with time slowing down to accommodate the creation of memory as details are layered upon the mind much like Talmeyr's urchins layered posters upon the arcade windows. Indeed in our most recent iteration of the project, Engberg has explicitly evoked Belle Epoque posters as both an element and an expansion upon the blended augmented-reality panoramas in which we might focus upon the differences between how he represented art, class, embodiment and legitimacy and the representations that emerge in those lithograph posters.

Pensky, in discussing Benjamin's focus upon the panorama in The Arcades Project, cites the particular type of modern, Schivelbuschian disembodiment wherein "The capacity to remain comfortably seated while the momentous and exotic rolls gently by... anticipates the long railway journey that would emerge as a paradigm for visual culture of the exotic, and offered the first rehearsal for the experience of cinema-going at the mall multiplex." (190). We might note in passing that the mall movie multiplex might easily be added to the catalogue of both the heterotopic places that Foucault identifies and those spaces in The Arcades Project where, in Pensky's phrase, "time, contra Hegel, seems to stop its steady forward flow for instance in the flâneur's slow tracing of the labyrinth of Parisian streets" (191). In suspending the present as Pensky suggests the historical panorama did, "revolv[ing] endlessly ; its history...precisely repetition, the absence of real change," (190) heterotopic and flâneurist spaces alike seem to me reminiscent of game space, with its ever-imminent replay, cycle, and latency.

This brings me to how the time-reversal mirror, le miroir à retournement temporel, might offer a way to think about the temporality of events in the still time of the suspended present, a consideration that for me bears upon the experience of the technical body in networked space. In Six Memos for the Next Millennium, Calvino speaks of how "Narrative time can also be delaying, cyclic, or motionless," and, neatly avoiding explicit matters of duration, simply says that "a story is an operation carried out upon the length of time involved, an enchantment that acts upon the passage of time, either contracting or dilating it." This is a process for which Calvino says "Sicilian storytellers use the formula 'lu cuntu nun mette tempu' (time takes no time in a story)." (35).

The time-reversal mirror represents a technology in which time not only takes no time, but loops back upon itself in a way that I think may be helpful as we come to characterize the co-evolutionary sense of punctuated temporality that we experience in, and share with, network beings in the form of the stories we come to tell not only in medias res but in digital media. The figure in the mirror seems always a step ahead to the figure who perceives her. Thus the overlay of successive, continual presences that 
comprise the medias res of digital media of necessity leaves the storyteller in a state of perpetual aftermath, able to speak only in le temps présent historique, the tense (in both the grammatical and psychological sense) of afterthought.

Here by way of parentheses, I would note that I titled this essay "Reflectional Encounters," having in mind not only how in French the word "afterthought" has among its translations both pensée après-coup and also réflexion; but also the spectrum of English-language definitions of reflection that range from both what a mirror does and what appears within it, to-aptly for the present consideration-"the anatomical sense of the bending back of a structure or body part upon itself." It is to this complex of transformations, reversals, and bendings-back that I want to turn in speculating upon what is increasingly our ability to multiply ourselves in la forme de multinaéité that the statement of the journées d'études imagined for the technical body.

I first heard of Mathias Fink's work from the physicist and visual/digital artist Dominique Peysson of EnsadLab, who as it happens is part of the Reflective Interaction group there, which, you may know, describes itself as "experimenting and modeling interactive and performative 'dispositifs' in art and design." Peysson shared the text of a mischievous presentation about the work of the Korean poet Yi Sang- part explication de texte, part explication du temps, part Borgesian fable, part Finkian conjecture. In an early Scientific American article Fink describes in simple terms for a general audience how arrays of time-reversal mirror or TRMs-already well known in optical researchfunction in ultrasonic applications :

If you stand in front of this array [of microphones and loudspeakers] and speak into it, anything you say comes back at you, but played in reverse. Your "hello" echoesalmost instantaneously-as "olleh." At first this may seem as ordinary as playing a tape backward, but there is a twist : the sound is projected back exactly toward its source. Instead of spreading throughout the room from the loudspeakers, the sound of the "olleh" converges onto your mouth, almost as if time itself had been reversed. Indeed, the process is known as time-reversed acoustics, and the array in front of you is acting as a "time-reversal mirror." (91)

Fink explains that "the magic of time-reversed acoustics is possible because sound is composed of waves" and the time-reversal mirrors depend upon two fundamental properties of waves, first how "when two of them pass through the same location, they reinforce each other if their peaks and troughs correspond, and they tend to cancel each other out if the peaks of one combine with the troughs of the other" ; and, second, "that the underlying physical processes of waves would be unchanged if time were reversed." (91)

Since the 90's Fink has explored practical applied research into using TRMs for medical, information processing, and other domains. But in the end of his 1999 article he speculates upon "the quantum wavefunctions that describe all matter" wondering "what kinds of tricks would be possible if time reversal were applied to the waves of quantum mechanics." (97). Peysson wittily picks up on this theme and speculates about possible applications of TRMs in another frontier, noting how "Parvenir au retournement temporel des ondes cérébrales donnerait accès à un transfert neuronal inversé, selon le principe du temps négatif." This leads her to speculate how negative time might "develop new modes of mental processes-through neural information transfer and modificationthat could generate an endless extension of the scope of thought, especially as concerns memory." (unpaginated, my translation) 

duration, our networked life seems to fundamentally affect our bodily experience-or our experience of embodiment-in the quotidian. It is as if we not only lived in parallel times but in parallel bodies in the way of Giorgio Agamben's sense of paraexistence, where : 
It is as if the form, the knowability, the features of every entity were detached from it, not as another thing, but as an intentio, an angel, an image. The mode of being of this intentio is neither a simple existence nor a transcendence; it is a paraexistence or a paratranscendence that dwells beside the thing ... so close that it almost merges with it, giving it a halo. (100.1) including our halos, as yet we always seem to return to our senses (a pun which revenir à la raison doesn't quite cover), returning if only because we live in a world of things. "The human," says Agamben, "is the being that, bumping into things and only in this encounter, opens up to the non-thinglike. And inversely, the human is the one that, being open to the non-thinglike, is, for this very reason, irreparably consigned to things." (100.2-100.3). Indeed Fink's work offers physical evidence that arguably our organic bodies become more in tune with things on account of the forays of our technical bodies. reversal through "a random set of 2,000 parallel steel rods immersed in a water tank." After the TRM array "detected an initial wavefront that was the part of the sound that threaded its way directly through the forest," it was "followed by a long chaotic wave... correspond[ing] to the portions of the initial pulse scattered along all possible paths between the rods." When they time-reversed these signals, the array first played back the signal of the "chaotically scattering forest" before the original pulse was regenerated at its source. Remarkably, however, according to Fink, the regenerated wave "focused to a spot six times smaller with the scattering rods than without them," a paradoxical result he explained because the "multiple-scattering medium acts somewhat like a focusing lens... thus improving its resolution sixfold." (3)

While it would be foolhardy to extend this metaphor to argue that time reversals in our networked lives extend our mortal lives, it may be that the bursts of chaos from which we re-emerge into the punctuated present-having been here once, here now once again- leave us in Proust's phrase "à la fois dans le moment actuel et dans un moment éloigné," (871) more focused, more where we are, in our embodied lives.

\section{BIBLIOGRAPHY}

Agamben, Giorgio. The Coming Community. Michael Hardt trans. Theory Out of Bounds. vol. 1.

Minneapolis : University of Minnesota Press. 1993.

Barad, Karen. “'Matter feels, converses, suffers, desires, yearns and remembers' : Interview with Karen Barad." In New Materialism : Interviews \& Cartographies. Ed. Rick Dolphijn et al. Ann Arbor : Open Humanities Press, 2011. Visited on May $1^{\text {st }}, 2014$.

<http://quod.lib.umich.edu/o/ohp/11515701.0001.001/1:4.3/--new-materialism-interviewscartographies?rgn=div2; view=toc>

---. Meeting the Universe Halfway: Quantum Physics and the Entanglement of Matter and Meaning. Durham : Duke University Press, 2007. 
Benjamin, Walter. The Arcades Project. Howard Eiland trans. Cambridge, MA : Belknap Press, 1999. Bergson, Henri. Time and Free Will : An Essay on the Immediate Data of Consciousness. 1913. F.L. Pogson trans. Dover : Dover Publications, 2001.

Bolter, Jay David, Maria Engberg, and Michael Joyce. "The Surface of Water.” 2014. Visited on May $1^{\text {st }}, 2014$.

<http://farnear.net/2012/10/06/panorama-narrative-project-the-surface-of-water-worlds-ofanders-zorn/>

Calvino, Italo. Six Memos for the Next Millennium. New York : Vintage, 1996.

Clark, T.J. “Reservations of the Marvellous," London Review of Books, vol. 22 No. $12 \cdot 22$ June 2000. 3-9

Clune, Michael W. Writing Against Time. Palo Alto : Stanford University Press, 2013.

Coover, Rod. "The Digital Panorama and Cinemascapes.” In Switching Codes ; Thinking Through Digital Technologies In The Humanities And Arts. Ed. Thomas Bartscherer et al. Chicago : University of Chicago Press, 2011. 199-217

Croisé dans le métro. 2014. Visited on May 1 $1^{\text {st }}, 2014$.

<http://www.croisedanslemetro.com/>

Deleuze, Gilles. Cinema 1 The Movement Image. Hugh Tomlinson and Barbara Habberjam trans. Minneapolis : University of Minnesota Press, 1986.

Eagleman, David M. “Brain Time," EDGE. 2008. Visited on May $1^{\text {st }}, 2014$.

<http://edge.org/conversation/brain-time>

Fink, Mathias. “Time-Reversed Acoustics.” Scientific American (November 1999) : 91-97.

Foucault, Michel. "Des Espaces Autres.” In Dits et Écrits. vol. 2. Ed. Daniel Defert et al. Paris : Gallimard, 2001. 1571-1581.

Hansen, Mark B. N. New Philosophy for New Media. Cambridge, MA/London : The MIT Press, 2004.

Hart, Claudia. “Theory : The Digital Any-Space-Whatever.” 2011. Visited on May 1 ${ }^{\text {st }}, 2014$.

<http://www.claudiahart.com/theory/theory9.html>

Joyce, Michael. Twilight, A Symphony. Watertown, MA : Eastgate Systems, 1996.

---. "The lingering errantness of place, the library as library," Othermindedness : the Emergence of Network Culture, Ann Arbor : University of Michigan Press, 2000. 67-80.

---. A Web of Caring: The book as it was to us, Eighth Annual Adam Helms Lecture, Svenska Förläggareföreningen and Stockholm University Library, 2001.

---. Was : Annales Nomadiques. Tucaloosa, AL : The University of Alabama Press, 2007.

Klose, Joachim. "Process Time and Temporality - from Whitehead to quantum physics." Preprint. 2008. Visited on May $1^{\text {st }}, 2014$.

<http://whiteheadresearch.org/occasions/conferences/beyond-metaphysics/papers/KloseJTimeAndTemporality.pdf>

Online Etymological Dictionary. “vignette.” 2014.

<http://www.etymonline.com/index.php?term=vignette>

Palmer, Jason. "Multiverse' theory suggested by microwave background.” BBC News. 2011.

Visited on May $1^{\text {st }}, 2014$.

<http://www.bbc.co.uk/news/science-environment-14372387> 
Pariyadath, Vani and David M. Eagleman. "The Effect of Predictability on Subjective Duration." San Francisco : PLOS ONE, November 28. DOI : 10.1371/journal.pone.0001264. Visited on May $1^{\text {st }}$, 2014.

<http://www.plosone.org/>

Pensky, Max. "Method and time : Benjamin's dialectical images." The Cambridge Companion to Walter Benjamin, Ed. David S. Ferris, Cambridge/NewYork, 2004.

Peysson, Dominique. "YI SANG | GNAS IY et le retournement temporel." 2010. Visited on May $1^{\text {st }}$, 2014.

<http://dominique.peysson.perso.sfr.fr/pagestravaux/yisang/confyisang.html>

Pribram, Karl. “Holonomic brain theory.” 2014. Visited on May $1^{\text {st }}, 2014$.

<http://www.scholarpedia.org/article/Holonomic_brain_theory>

Proust, Marcel. A la recherche du temps perdu. vol. 3. Paris : Gallimard, Editions de la Pléiade, 1954. 871.

Reflective Interaction Research Program. École Nationale Supérieure des Arts Décoratifs. 2014. Visited on May $1^{\text {st }}, 2014$.

$<$ http://diip.ensadlab.fr/fr/>

Schellinx, Harold. “And what about Yi Sang ?” (... à Paris [iv]).” SOUNDBLOG. 2010. Visited on May $1^{\text {st }}, 2014$.

<http://www.harsmedia.com/SoundBlog/Archief/00744.php>

Schivelbusch, Wolfgang. The Railway Journey : the Industrialization of Time and Space in the 19th Century. Berkeley : University of California Press, 1987.

Talmeyr, Maurice. La cité du sang. Paris : Perrin \& Cie, Libraires-Editeur, 1901.

Taylor, Mark C. Hiding. Chicago : University of Chicago Press, 1997.

\section{NOTES}

1. “Corps techniques et environnements connectés," June 11-12, 2014, Université Paris 8, SaintDenis, France.

$<\mathrm{http}$ ///sujetdigital.labex-arts-h2h.fr/fr/content/corps-techniques-et-environnementsconnect\%C3\%A9s>

\section{ABSTRACTS}

An American author of digital hypertexts and innovative fictions reflects upon reflection. Benjamin's notion of the dialectical image as well as the suspended present tense of Foucault's heterotopic networked time inform reflections upon how Michael Joyce's earlier digital and print fictions explore a punctuated temporality where the future and the past intermix and a newness bursts forth. Finally in discussing current collaborative work via speculations by physicist and 
artist Dominique Peysson, the time reversal mirror of the physicist Mathias Fink is offered as a way to consider the multinaéité of the technical body in networked space.

Dans cet essai, un auteur américain d'hypertextes numériques et de fictions innovantes réfléchit à la réflexion. Ces réflexions sont informées par la notion d'image dialectique développée par Benjamin, ainsi que par le temps présent suspendu propre au temps hétérotopique en réseau défini par Foucault. Elles portent sur la manière dont les premières fictions imprimées et numériques de Michael Joyce explorent une temporalité ponctuée où passé et futur s'entremêlent, et c'est ainsi qu'émerge la nouveauté. Enfin, s'appuyant sur les hypothèses du physicien et artiste Dominique Peysson et sur le miroir à retournement temporel de Mathias Fink, le présent essai propose une analyse de la multinaéité du corps technique dans un espace en réseau à partir d'une œuvre collaborative en cours.

\section{INDEX}

Subjects: Digital arts

Mots-clés: récit, temporalité ponctuée, heterotempora, multinaéité, incarnation, retournement temporel

Keywords: narrative, punctuated temporality, heterotempora, multinaéité, embodiment, time reversal

\section{AUTHORS}

MICHAEL JOYCE

Professor of English

Vassar College

mijoyce@vassar.edu 